\title{
4 \\ REFLECTIONS ON THE
CIVILIAN COUP IN FIJI
}

Tevita Baleiwaqa

I stepped on to the Fenner Hall shuttle at 11:07 on the morning of 19 May 2000. I stopped short on the door when I heard the 11 o'clock Australian Broadcasting Corporation news, '...there is an unconfirmed report of a coup in Fiji!' But as the shuttle turned on to Northbourne Avenue, the newsreader confirmed that Mahendra Chaudhry and his cabinet had been taken hostage. I was shocked but excited. This is a personal reflection on this crisis.

This paper reflects on the coup in Fiji. The coup itself was a strategic operation. The coup operation, from the drawing board to execution, can be detailed and presented as a discussion paper on the subject of toppling governments. But the subject of the coup, the Labour government of the Republic of Fiji, is pregnant with all categories of issues for discussion. Therefore in this reflection, I prefer to select current issues within the Fijian section of the population in Fiji, which directly forced this coup to take place. I do not intend to judge the coup as right and wrong, for what is done cannot be undone. Furthermore, there are many experiences which can be used as issues for reflection, like the hostages' experiences, yet I have chosen issues which are institutional rather than personal for my reflection. I will therefore reflect on momentary angst deduced from this crisis. Do not judge me as a presumptuous Stoic, for I am conscious of the twinge each individual citizen in Fiji is going through.

I called the General Secretary of the Methodist Church in Fiji, the Reverend Laisiasa Ratabacaca, and asked him of the Church's point of view regarding the coup. He gave me a rainbow answer, assuring me that 
this turmoil will soon be over for a new era of Fijian history to be born. I base my selection of issues on that eternal rainbow from Epworth House in Suva, and not on the temporal flood which overflowed only for 40 nights. The civilian coup in Fiji happened when I was working on the Reverand John Hunt and Joeli Nau's legends of the mythological civil war and the successive flood at Nakauvadra. It was an event whereby the chiefs of Fiji waged war with one another. The Nakauvadra flood did not have a rainbow in the sky, but the birth of chiefly titles from that flood to become the institution of hope for the Fijian society could be a good moral to the legend. I will not deviate into this subject for it is in my thesis. I prefer to refresh my mind with current issues engulfing Fiji before I return to Nakauvadra and complete my chapter on Fiji divinity.

I must briefly clarify the form of addressing chiefly names and Fijian traditional political boundaries in this article. I prefer to address Fijian chiefs by Ratu before their personal names, due to my respect for the families concerned. The chiefly families in Fiji are divided into three major confederacies. They are Kubuna, of which Bau is the head; Burebasaga, under the leadership of Rewa; and the Tovata, under the leadership of the Cakaudrove chiefs. These confederacies existed before the nineteenth century. Rewa, for instance, had been acknowledged as the political capital of southern Viti Levu and adjacent islands of Vatulele, Beqa and Kadavu. Bau later emerged as the political capital of the northern half of Viti Levu in the mid-nineteenth century. The amalgamation of the northern and eastern chiefs, to be called the Tovata, was the result of Ratu Goleanavanua and Enele Ma'afu'out'itonga's efforts to set up their own sovereign government. Even though these traditional political systems were established beyond the nineteenth century, the customs and laws are still enforced within the modern Fijian society. Within these three confederacies of Kubuna, Burebasaga and Tovata, there are fourteen provinces. In Kubuna, there is Tailevu, Naitasiri, Ra, Lomaiviti and parts of Ba. Burebasaga consists of the provinces of Rewa, Nadroga, Serua, Namosi, Kadavu and parts of Ba. The Tovata confederacy consisted of Cakaudrove, Bua, Macuata and Lau. The structure of the chiefly system varies from province to province. In Tailevu for instance, there exist three other divisions, namely Bau, Verata and Nakelo. Ra consisted of four 
chiefly districts, Saivou, Rakiraki, Nalawa and Nakorotubu. These confederacies and provinces formed the traditional basis of contemporary Fijian politics. Beneath the modern politics of the Fijian political party, the Soqosoqo ni Vakavulewa ni Taukei, there is an interflow of a strong combination of Fijian traditional and chiefly politics.

The issue of Fijian alarm at losing political control. Mahendra Chaudhry's Labour Party had overwhelmingly claimed victory in the May 1999 general election in Fiji. The ruling Fijian political party lost, with its coalition partner, the Indian-dominated National Federation Party. Before a year had gone while in office, the Labour government began to hear the voice of Fijian political discontent. It rather surprised me that the coup had to be staged so early, in relation to the three public protest marches. I had thought that the Fijian opposition to the Labour government in Fiji would continue to keep 'Mahen's nose to the ground' by public pressure. Hence my saying-so inclinations towards those protest marches in Suva. The mere fact of three public protest marches in three months should have given to any analyst indication of something of this calibre. The Police Commissioner, Colonel Isikia Savua, was not surprised. He was sharp enough to cage it, but the then Prime Minister Mahendra Chaudhry ignored his security assessment warnings.

The major element of my surprise was not Mahendra, but Ratu Sir Kamisese Tuimacilai Kapaiwai Mara, the Tui Nayau, and Ratu Josefa Iloilovatu, the Tui Vuda, as President and Vice President respectively. Ratu Iloilovatu himself is a vasu to Cakaudrove. In a coup situation, like in Fiji, where one replaces a government thought to be arrogant in one's own eyes, the Head of State remains unaffected. Unless you overthrow the Constitution, then the coup can affect the Head of State. What surprised me most, therefore, was the toppling of a government under the constitutional noses of two ranking Fijian chiefs. Once the executive government is sacked, how can these two chiefs and the Constitution function? It surprised me that sentiments had reached this extreme stage where the proletariat had undermined the aristocrat's constitutional footing.

I tried to regain my thoughts and tried to place myself in the mind of those who staged the coup. I did not know who they were really. There 
must have been a lot of recent political developments in Suva that I do not know, apart from those news flashes released through the two news web sites, Fijilive and Fiji Village. Even though surprised, I was thrilled also after hearing the news. It is now an exciting opportunity for thinkers to analyse latent social forces of Fijian societies that need only an event like this to reawaken them. This is another chance for the nation to examine its heart and other state vital organs; and especially to review the spirit of Fijian island political and social life.

The issue of racial politics. The conflicting political goals of the two major races in Fiji commanded Fiji's political scape. What are these ends? This is the question that animates my academic curiosity. Let me reflect on this question on a larger political scale in order to contextualise the coup d'état. The Fijian political goal is total political control over their islands. But to the Indo-Fijian population, it is political power sharing. The confrontation of the two ends caused the current crisis in Fiji. The two former Fijian Prime Ministers, Ratu Sir Kamisese Tuimacilai Kapaiwai Mara and Sitiveni Rabuka, tried their best to deal with these two ends but they were toppled through ballot by Fijians who did not want to share power with Indo-Fijians. When Mahendra Chaudhry, an Indo-Fijian Prime Minister, came into power, the Fijians toppled him by force, on the thought that the ballot paper was too late. They saw that it was not going to be power sharing but power lost, even though Mahendra's Cabinet had more Fijians than Indo-Fijians.

These conflicting political goals, in my view, cannot be related or resolved in Parliament. The concept of multiracialism, which had been Ratu Tuimacilai's dream, could have been settled first outside Parliament. In fact, in rural areas of Macuata and Ba, Fijians and Indians are bilingual. Bi-linguism is a good base for multiracialism. The problem then was how to translate the bilingualism of Ba and Macuata into a political reality. Parliamentary language is English but, under the skin, it is Fijians and Indians. The Fiji Parliament should be based on the answer to the two conflicting ends. It should not be the forum where we try to find the answer to the two political ends. The attempt to design a common future, identity and people in Fiji's multiracial mix failed when first George Speight 
and then Commodore Frank Bainimarama abrogated the 1997 Constitution. The failure of the 1997 Constitution does not mean the failure of racial harmony in Fiji. Fijians were not satisfied with how their political life was constituted in the 1997 Constitution. Hence their public protest.

The Fijians wanted to be respected in all levels of the government of their island state. I have therefore formed a term to identify what they want. Fiji is an 'island state' with island mentalities. In this kind of mentality, boundary is an important issue. Boundary is a compound of political, religious, geographical and historical ideas. Boundaries are not only cartographic lines but also rivers, mountains, seashores, islets and reefs. It is an island because there is a sea around it. In this 'island Christian context', the Fijian view of humanity is an all-embracing totality. This totality is expressed in the concept vanua, connected yet unique. The norms of the vanua are expressed in Fijian natural hospitality embracing, caring and loving, and with the widest smile in the world. He has his own set of customs and laws, which govern life and property. The British colonial administration, by regulation and ordinance, preserved most of these customs and laws.

The Fijians, I believe, do not intend to isolate the Indo-Fijian from this cosmological totality. And neither will they try to force a revocation of citizenship or deprival of Indians' voting rights. They do acknowledge their presence and contribution. But when it comes to political power, Fijians prefer all politicians to respect Fijian customs and laws, especially with recourse to the Great Council of Chiefs. All they want is respect of what is Fijian in a Christian and an island situation. viti is not only their land, but their islands as well. This is all they have got. Both Viti Levu and Vanua Levu islands have been surveyed, claimed and registered. Fijian tribes own approximately 83 per cent of the Fijian landmass. Even the residence of the Head of State in Suva is on native land. The customs and laws, which governed these lands, are all according to Fijian customs. When the Labour government tried to play free politics, irrespective of customary laws and regulations and not considering the chiefly system, unconscious of traditional boundaries, taking advantage of the supremacy of the Constitution over Customary Laws, which govern land ownership, the 
Fijians responded by public protests. Anglo-continental definition of democracy had to be redefined through island standards to give democracy its own unique island features. Fiji must be given the opportunity to redefine for itself this unique democratic mixture without outside interference. If it is not Fijian, it has no future in Fiji. If democracy is the love of humanity, then Fijians are prepared for it, in their own customs and traditions. But they will not forfeit their heritage in exchange for a democracy defined by another society. What Fiji is going through is a constitutional crisis. The world should allow Fiji to shape its own definition of democracy.

The issue of Fijian political leadership. This issue emerged when Fijians questioned Sitiveni Ligamamada Rabuka's morality. It was never an issue until 1987. After Independence, Fijians saw in front of them three prominent chiefs, Ratu George Kadavulevu Cakobau, the Vunivalu of Bau; Ratu Penaia Kanatabatu Ganilau, the Tui Cakau, and Ratu Tuimacilai. Their patriotism to these chiefs, especially to Ratu Kadavulevu and Ratu Penaia, were forged in battle and rugon by fields. Ratu Tuimacilai spent most of his time studying and returned to enter the colonial service. The Fijian soldiers who went on peace-keeping duties in the Middle East remember him for composing a song about them while they stood on duty. All three entered the Legislative Assembly and then into the Fiji Parliament, succeeding one another as Governor-General and President of the Republic of the Fiji Islands. I must say that the catchphrase in the current crisis, the end of the Mara dynasty, is a poignant axiom. The current dynasty, for me, is not a Mara dynasty, but the Cakobau, Ganilau and Mara dynasty. Ratu Sir Tuimacilai may be the last survivor, yet he is merely upholding their corporate legacy. As I compare how Ratu Sir Penaia handled the 1987 crisis and how Ratu Sir Tuimacilai handled this one, they have their own style of doing their duties. Ratu Sir Penaia was a man of the vanua and Ratu Sir Tuimacilai a man of letters. It is my zealous longing for the three families to come together and unite the fourteen provincial chiefly families so that Fijians may once more stand united. I do have a lot of faith in the new generations of chiefs, such as Adi Samanunu Talakuli Cakobau, Ratu Epeli Ganilau, Adi Koila Nailatikau, Ratu Filipe Tuisawau, Ratu Sakiusa Makutu and Ratu Inoke Kubuabola. The shadows of the 
former generation might be too huge for the latter generation, yet given the chance to lead, they will truly illustrate that they were born Fijian chiefs. The short period from 1987 to 2000 showed that the Fijians were receptive to the idea of persons other than those from their chiefly ranks to lead them politically. Their political loyalty will be offered if they see their chiefs uniting and leading them. The intricate network of Fijian tribalism which exists on village level summons these young chiefs to stand to their calling as Fijian chiefs. They were born to be Fijian chiefs.

As I write this short piece, the hostage crisis in Fiji has not been resolved. I wish I were in Suva to experience the anxiety, frustration and share in the hope of those who struggle otherwise for a happy Fiji. I found it hard to focus on my thesis, including a seminar on Fijian divinity. I am in the Coombs Building of the Australian National University, from where I am making these distant reflections, but my mind and heart are in Suva. 